\title{
Comparative Analysis of the Effectiveness of Rice Husk Pellets and Charcoal AsFuel For Domestic Purpose
}

\author{
Tokan, A., Muhammad, M. H., Japhet, J. A. andKyauta, E. E. \\ Department of Mechanical EngineeringAbubakarTafawaBalewa University, Bauchi, Nigeria
}

\begin{abstract}
In an effort to provide an affordable firewood and charcoal alternative to the rural households in Nigeria, Pellets were produced from rice husk using a mould and a hydraulic press at three (3) pressures of compaction of 28MPa, 31MPa and 34MPa and three (3) particles sizes of $212 \mu \mathrm{m}, 300 \mu \mathrm{m}$ and $425 \mu \mathrm{m}$. The moisture content, ash content, bulk density, porosity index, and the calorific value were determined. With water boiling test, $100 \mathrm{~g}$ of pellet sample $P_{1}$, achieved $100^{\circ} \mathrm{C}$ in 6 minutes to boil $500 \mathrm{ml}$ of water while $100 \mathrm{~g}$ of pellet samples $P_{6}$ and $P_{7}$ each achieved $100^{\circ} \mathrm{C}$ each in 8 minutes to boil $500 \mathrm{ml}$. Comparative studies of the rice husk pellets and charcoal was conducted, the results showed that $100 \mathrm{~g}$ of pellet burns uniformly under free convection with pale yellow flame and very little smoke while $100 \mathrm{~g}$ of charcoal burns irregularly and would require forced convection. With water boiling test, $100 \mathrm{~g}$ of charcoal sample achieved $100^{\circ} \mathrm{C}$ in 14 and 20 minutes to boil $500 \mathrm{ml}$ of water for $C_{1}$ and $C_{2}$ respectively. $C_{3}$ did not achieve $100^{\circ} \mathrm{C}$. With calorific value ranging from $15.129-17.589 \mathrm{MJ} / \mathrm{kg}$, and good physical and combustion characteristic of the rice husk pellet, it can conveniently substitute for charcoal as a domestic fuel.
\end{abstract}

Keywords:Ash, Bulk density, Calorific value, Charcoal, Moisture, Pellet, Porosity,

\section{Introduction}

Rice husk is a by-product of rice milling. The prevalence and year-round production of rice crops on both an industrial and small scale means that rice husks are an attractive biomass fuel because they are not only readily available in large quantities but are also easy to collect. Furthermore, combusting the husk solves the problem of waste husk disposal. In Nigeria, a large quantity of rice husks are produced annually and these residues are left to rot away or they are burned like other agricultural wastes. These residues could however, be used to generate heat energy for domestic and industrial cottage applications [1].

The availability of energy for domestic use in Nigeria continues to pose a formidable challenge, especially with the high cost of cooking gas and kerosene and the environmental problems associated with firewood and charcoal production. Alternative forms of energy need to be sourced. This has necessitated the need to improve on the use of agro wastes such as rice-husk as alternatives.

One strategy to increase the accessibility of biomass heating fuel is densification of the material. Densification of biomass is a process of reducing the bulk volume of the material [2]. They are converting the low or negative value wood, forest, agricultural and municipal waste to a valuable product. (E.g. pellet, cubes, $\log$ and briquette) that can be easily burned more efficiently. Biomass densification represents a set of technologies for the conversion of biomass into a fuel. The technology is also known as briquetting and it improves the handling characteristics of the materials for transport, storing etc. This technology can help in expanding the use of biomass in energy production, since densification improves the volumetric calorific value of a fuel, reduces the cost of transport and can help in improving the fuel situation in rural areas. Briquetting is one of several agglomeration techniques which are broadly characterized as densification technologies. Agglomeration of residues is done with the purpose of making them denser for their use in energy production. Raw materials for briquetting include waste from wood industries, loose biomass and other combustible waste products [3].

Pellets are an important renewable energy source that benefits the environment, provides jobs to local and national economies and is easily manageable in small-scale domestic systems. Domestic households cover about $27 \%$ of total energy consumption in the European Union Member states. The heat market related to domestic households can be best addressed by using pellets as this fuel is as convenient to use as fossil fuels[4]. The potential for the use of biomass as energy source in Nigeria is very high because about $80 \%$ of Nigerians are rural and semi-urban dwellers and they solely depend on biomass for their energy needs. Particularly, fuel wood accounts for about $90 \%$ of the total wood demand from the forest[5].This work is aimed at evaluating rice husk pellet as an alternative source of energy for household purpose and its advantages for domestic heating systems against charcoal. 


\subsection{Raw material procurement}

\section{Materials And Methods}

The rice husk was collected from a rice mill at YelwaTudu, it was grinded into a powdered form and sieve through screens to obtain three particle sizes of $212 \mu \mathrm{m} 300 \mu \mathrm{m}$ and $425 \mu \mathrm{m}$. Any wood will make useable charcoal, but different woods make different qualities of charcoal. The woods use in the cause of this research for the charcoal to evaluate the cooking efficiency of the rice husk pellets are; Anageisusleocarpus (Marke), Butyrospermumparkii / B. paradoxum (Kadanya), Pericopsislaxiflora (Makarho). The reason was because these woods are readily available here in Bauchi.

\subsection{Pellet production}

The Rice husk pellet was produced by compaction in a mould with the following dimensions $12 \mathrm{~mm}$ diameter and $20 \mathrm{~mm}$ length at three (3) pressures of $28 \mathrm{MPa}, 31 \mathrm{MPa}$ and $34 \mathrm{MPa}$. The rice husk powder was first mixed with a little water directly to moisten it before loading in the mould. Water acts as both a binding agent and a lubricant. Water helps develop Vander Waals' forces by increasing the area of contact between particles [3]. The production of the pellet was done using a manually operated hydraulic press fixed with a pressure gauge for varying the pressure and a simple mould. The setup is shown in plate I and the pellet produced in plate II.

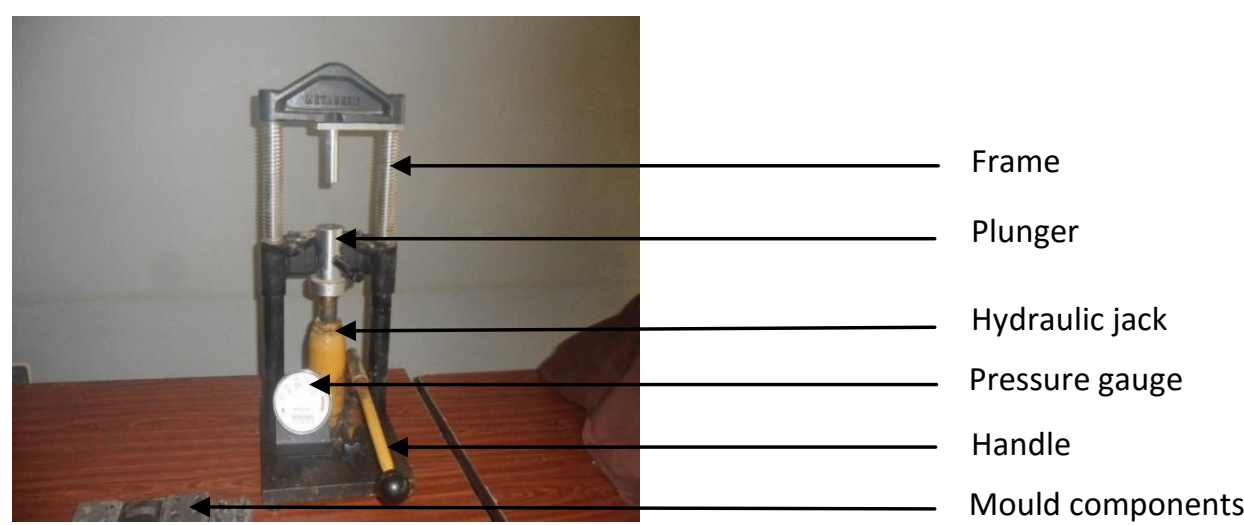

Plate I: Manual Hydraulic Press Unit

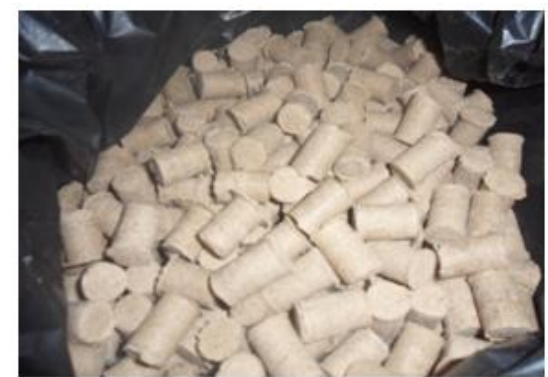

Plate II: Pellets produced

\subsection{Carbonization process}

Freshly cut pieces of hardwood about 4 feet long and 6 to 8 inches in cross section were piled in mounds. Freshly cut leaves were used to cover the wood then Earth is mounded over it to give a firm enclosure(an earthen kiln), but was not too tightly packed to prevent air from leaking through to the wood. A small opening was left; where the wood was ignited when the wood has ignited, the opening was covered. The number of days to coal the wood charge was 3 days.

\subsection{Determination of bulk density}

Bulk density measurement was determined according to the method of ASABE 269.5 [6], which states that for all densified products (cubes, pellets, or crumbles); use a cylindrical container with a height-diameter ratio within the range of 1.25-1.50. The diameter of the container must be at least ten times larger than the largest dimension of a single product. The bulk density was determined by calculating the ratio of the mass to the volume occupied. A cylindrical metal container with $100 \mathrm{~mm}$ diameter and $130 \mathrm{~mm}$ height was weighed. 
The bulk density measurement was repeated five times and the average value and range were reported. The bulk density was calculated from the relationship:

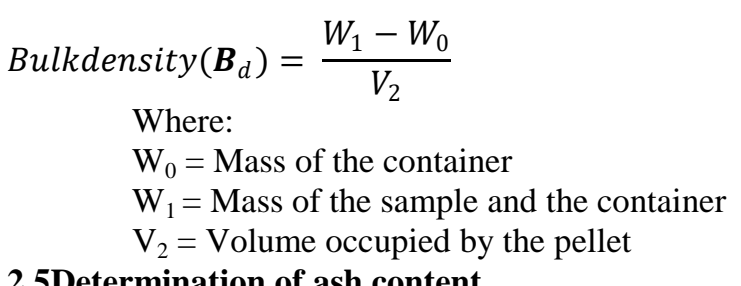

\subsection{Determination of ash content}

Ash content was determined using the ASTM D 2017 [7], 6 grams of each pellet and charcoal samples were placed in a pre-weighted crucible and were weighed out. The samples were incinerated in a furnace at $760^{\circ} \mathrm{C}$ until complete ashing was achieved. The crucibles were left over night to cool. The cooled samples were then weighed. The ash content was calculated by using the equation:

$$
\begin{aligned}
& \text { Ashcontent }(\%)=\frac{\left(W_{5}-W_{3}\right) \times 100 \%}{W_{4}-W_{3}} \\
& \text { Where: } \\
& \mathrm{W}_{3}=\text { Weight of the crucible, } \\
& \mathrm{W}_{4}=\text { Weight of the crucible }+ \text { sample before incineration and } \\
& \mathrm{W}_{5}=\text { Weight of the crucible + sample after incineration }
\end{aligned}
$$

\subsection{Determination of moisture content}

The moisture content of each pellet sample was determined by the oven drying method. This was carried out at temperature of $103 \pm 2{ }^{\circ} \mathrm{C}$ in accordance with the ASTM D 1037 [8]. The samples were dried in the oven for 1 hour. The moisture content was calculated by using the equation:

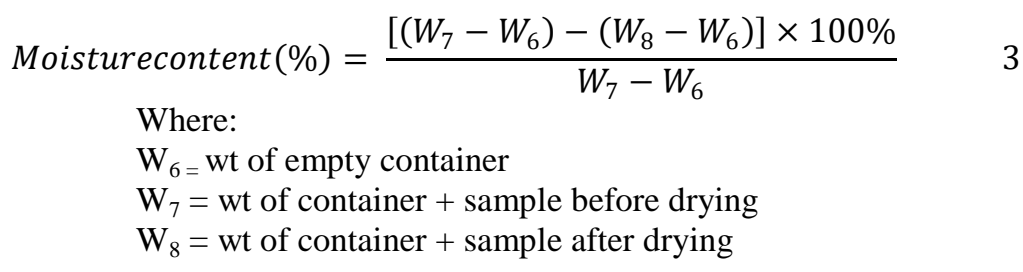

\subsection{Determination of porosity index}

The porosity of each pellet sample was determined based on the amount of water two pieces of each pellet sample was able to absorb. Each pellet sample was immersed in water at room temperature for 30 s. The porosity index was calculated as the ratio of the mass of water absorbed to the mass of the sample immersed in the water [9]. The test was replicated five times and the average value recorded:

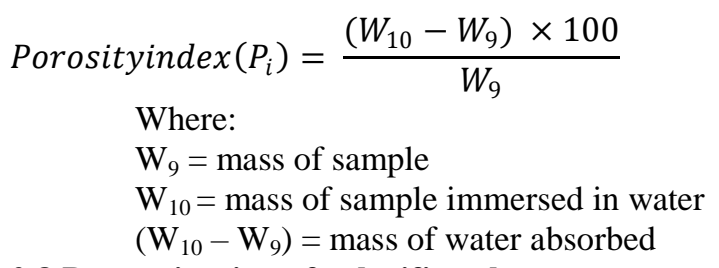

The net calorific values of the 12 samples were determined by using the relationship below [10]:

$$
\begin{aligned}
& N C V= 18.7(1.0-A C-M C)-(2.5 M C) \\
& \text { Where: } \\
& \text { NCV }=\text { net }(\text { lower }) \text { calorific value } \\
& \text { AC }=\text { ash content } \\
& \text { MC }=\text { moisture content }
\end{aligned}
$$

\subsection{Determination of burning rate}

Burning rate is the ratio of the mass of the fuel burnt (in grams) to the total time taken (in minute) [11]

Burningrate $\left(B_{R}\right)=\frac{\text { massoffuelconsumed }(g)}{\text { totaltimetaken }(\min )}$ 
$100 \mathrm{~g}$ of each pellet and charcoal samples were weighed using an electronic weighing machine. Each sample at the time of burning was put in a domestic stove. The combustion was initiated by the addition of a little kerosene and igniting with matches. The temperature of the burning samples was taken by means of thermocouple at every two minute intervals using a stop watch until it was completely burnt. The temperature was taking from a particular point on the stove for all the samples.

\subsection{Water boiling test}

This was carried out to compare the cooking efficiency of each pellet sample to the charcoal. It measures the time taken for each pellet and charcoal sample to boil an equal volume of water under similar conditions. $100 \mathrm{~g}$ of each pellet and charcoal sample was used to boil $500 \mathrm{ml}$ of water using small stainless steel pot and domestic stove [12].

\subsection{Results}

\section{Results And Discussion}

The results of the experiments carried out on the properties of the rice husk pellet are presented on table 1 to 11

Table 1: The description of pellet samples

\begin{tabular}{|l|l|l|l|l|l|l|l|l|l|}
\hline Samples & $\mathrm{P}_{1}$ & $\mathrm{P}_{2}$ & $\mathrm{P}_{3}$ & $\mathrm{P}_{4}$ & $\mathrm{P}_{5}$ & $\mathrm{P}_{6}$ & $\mathrm{P}_{7}$ & $\mathrm{P}_{8}$ & $\mathrm{P}_{9}$ \\
\hline Particles size $(\mu \mathrm{m})$ & 425 & 425 & 425 & 300 & 300 & 300 & 212 & 212 & 212 \\
\hline Compaction pressure $(\boldsymbol{M P a})$ & 28 & 31 & 34 & 28 & 31 & 34 & 28 & 31 & 34 \\
\hline
\end{tabular}

Table 2: The Description of Charcoal Samples

\begin{tabular}{|l|l|l|l|}
\hline $\begin{array}{l}\text { Sources of } \\
\text { charcoal }\end{array}$ & $\begin{array}{l}\text { Anogeissusleiocarpus } \\
\text { (Marke) }\end{array}$ & $\begin{array}{l}\text { Butyrospermumparkii / B. } \\
\text { paradoxum (Kadanya) }\end{array}$ & $\begin{array}{l}\text { Pericopsislaxiflora } \\
\text { (Makarho) }\end{array}$ \\
\hline Charcoal samples & $\mathrm{C}_{1}$ & $\mathrm{C}_{2}$ & $\mathrm{C}_{3}$ \\
\hline
\end{tabular}

Table 3: The result of bulk density of pellet samples

\begin{tabular}{|l|l|l|l|l|l|l|l|l|l|}
\hline & $\mathbf{P}_{\mathbf{1}}$ & $\mathbf{P}_{\mathbf{2}}$ & $\mathbf{P}_{\mathbf{3}}$ & $\mathbf{P}_{\mathbf{4}}$ & $\mathbf{P}_{\mathbf{5}}$ & $\mathbf{P}_{\mathbf{6}}$ & $\mathbf{P}_{\mathbf{7}}$ & $\mathbf{P}_{\mathbf{8}}$ & $\mathbf{P}_{\mathbf{9}}$ \\
\hline Mass of container, $\mathbf{W}_{\mathbf{0}} \mathbf{( k g )}$ & .0736 & .0736 & .0736 & .0736 & .0736 & .0736 & .0736 & .0736 & .0736 \\
\hline Mass of sample + container, $\left.\mathbf{W}_{\mathbf{1}} \mathbf{( k g}\right)$ & .5979 & .6300 & .6407 & .8050 & .8143 & .8236 & .8443 & .8650 & .8665 \\
\hline Range (kg) & .0029 & .0033 & .0028 & .0026 & .0022 & .0021 & .0044 & .0026 & .0022 \\
\hline Volume occupied, $\left.\mathbf{V}_{\mathbf{2}} \mathbf{( m}^{\mathbf{3}}\right)$ & .001 & .001 & .001 & .001 & .001 & .001 & .001 & .001 & .001 \\
\hline Bulk density, $\mathbf{B}_{\mathbf{d}} \mathbf{( k g} \mathbf{m}^{\mathbf{3}}$ & 524.3 & 556.4 & 567.1 & 731.4 & 740.7 & 750.0 & 770.7 & 791.4 & 792.9 \\
\hline
\end{tabular}

Table 4: The result of ash content of pellet samples

\begin{tabular}{|l|l|l|l|l|l|l|l|l|l|}
\hline & $\mathbf{P}_{\mathbf{1}}$ & $\mathbf{P}_{\mathbf{2}}$ & $\mathbf{P}_{\mathbf{3}}$ & $\mathbf{P}_{\mathbf{4}}$ & $\mathbf{P}_{\mathbf{5}}$ & $\mathbf{P}_{\mathbf{6}}$ & $\mathbf{P}_{\mathbf{7}}$ & $\mathbf{P}_{\mathbf{8}}$ & $\mathbf{P}_{\mathbf{9}}$ \\
\hline Weight of crucible, $\mathbf{W}_{\mathbf{3}}(\mathbf{g})$ & 61.9 & 51.2 & 63.8 & 62.4 & 96.6 & 110.2 & 66.3 & 90.3 & 114.9 \\
\hline $\begin{array}{l}\text { Weight of crucible + sample before } \\
\text { incineration } \mathbf{W}_{\mathbf{4}}(\mathbf{g})\end{array}$ & 67.8 & 56.9 & 69.2 & 69.8 & 102.6 & 115.9 & 72.3 & 96.7 & 120.2 \\
\hline $\begin{array}{l}\text { Weight of crucible + sample after } \\
\text { incineration } \mathbf{W}_{\mathbf{5}}(\mathbf{g})\end{array}$ & 62.4 & 51.5 & 64.0 & 63.0 & 97.4 & 110.8 & 67.2 & 91.2 & 115.6 \\
\hline Ash content (\%) & 8.5 & 6.0 & 3.7 & 10.5 & 13.3 & 10.5 & 15.0 & 14.0 & 13.2 \\
\hline
\end{tabular}

Table 5: The result of ash content charcoal samples

\begin{tabular}{|l|l|l|l|}
\hline & $\mathbf{C}_{\mathbf{1}}$ & $\mathbf{C}_{\mathbf{2}}$ & $\mathbf{C}_{\mathbf{3}}$ \\
\hline Weight of crucible, $\mathbf{W}_{\mathbf{3}}(\mathbf{g})$ & 58.1 & 72.2 & 69.6 \\
\hline Weight of crucible + sample before incineration $\mathbf{W}_{\mathbf{4}}(\mathbf{g})$ & 62.3 & 79.5 & 76.0 \\
\hline Weight of crucible + sample after incineration $\mathbf{W}_{\mathbf{5}}(\mathbf{g})$ & 58.8 & 72.5 & 69.7 \\
\hline Ash content $(\%)$ & 16.7 & 4.1 & 1.6 \\
\hline
\end{tabular}

Table 6: The results of moisture content of pellet samples

\begin{tabular}{|l|l|l|l|l|l|l|l|l|l|}
\hline & $\mathbf{P}_{\mathbf{1}}$ & $\mathbf{P}_{\mathbf{2}}$ & $\mathbf{P}_{\mathbf{3}}$ & $\mathbf{P}_{\mathbf{4}}$ & $\mathbf{P}_{\mathbf{5}}$ & $\mathbf{P}_{\mathbf{6}}$ & $\mathbf{P}_{\mathbf{7}}$ & $\mathbf{P}_{\mathbf{8}}$ & $\mathbf{P}_{\mathbf{9}}$ \\
\hline wt of empty container $\mathbf{W}_{\mathbf{6}} \mathbf{( g )}$ & 24.1 & 24.0 & 23.9 & 24.0 & 23.7 & 24.7 & 24.1 & 23.8 & 24.0 \\
\hline $\begin{array}{l}\text { wt of container + sample before } \\
\text { drying } \mathbf{W}_{\mathbf{7}}(\mathbf{g})\end{array}$ & 34.3 & 34.1 & 33.8 & 35.7 & 34.2 & 34.2 & 34.5 & 34.5 & 33.6 \\
\hline $\begin{array}{l}\text { wt of container + sample after } \\
\text { drying } \mathbf{W}_{\mathbf{8}}(\mathbf{g})\end{array}$ & 33.8 & 33.8 & 33.6 & 35.4 & 33.9 & 33.9 & 34.2 & 34.1 & 33.1 \\
\hline Moisture content \% & 4.9 & 3.0 & 2.0 & 2.6 & 2.9 & 3.2 & 2.9 & 3.7 & 5.2 \\
\hline
\end{tabular}


Table 7: The result of moisture content of charcoal

\begin{tabular}{|l|l|l|l|}
\hline & $\mathbf{C}_{\mathbf{1}}$ & $\mathbf{C}_{\mathbf{2}}$ & $\mathbf{C}_{\mathbf{3}}$ \\
\hline wt of empty container $\mathbf{W}_{\mathbf{6}}(\mathbf{g})$ & 23.8 & 24.1 & 24.2 \\
\hline wt of container + sample before drying $\mathbf{W}_{\mathbf{7}}(\mathbf{g})$ & 34.5 & 34.2 & 34.4 \\
\hline wt of container + sample after drying $\mathbf{W}_{\mathbf{8}}(\mathbf{g})$ & 34.5 & 34.0 & 34.4 \\
\hline Moisture content $\%$ & 0.0 & 2.0 & 0.0 \\
\hline
\end{tabular}

Table 8: The results of porosity index of pellet samples

\begin{tabular}{|l|l|l|l|l|l|l|l|l|l|}
\hline & $\mathbf{P}_{\mathbf{1}}$ & $\mathbf{P}_{\mathbf{2}}$ & $\mathbf{P}_{\mathbf{3}}$ & $\mathbf{P}_{\mathbf{4}}$ & $\mathbf{P}_{\mathbf{5}}$ & $\mathbf{P}_{\mathbf{6}}$ & $\mathbf{P}_{\mathbf{7}}$ & $\mathbf{P}_{\mathbf{8}}$ & $\mathbf{P}_{\mathbf{9}}$ \\
\hline Mass of sample $\mathbf{W}_{\mathbf{9}}(\mathbf{g})$ & 4.7 & 4.7 & 4.8 & 5.1 & 4.3 & 4.2 & 4.8 & 5.1 & 4.9 \\
\hline $\begin{array}{l}\text { Mass of sample immersed in } \\
\text { water } \mathbf{W}_{\mathbf{1 0}}(\mathbf{g})\end{array}$ & 9.3 & 9.2 & 9.3 & 7.3 & 5.8 & 5.6 & 5.5 & 5.8 & 5.5 \\
\hline $\begin{array}{l}\text { Mass of water absorbed } \mathbf{W}_{\mathbf{1 0}}- \\
\mathbf{W}_{\mathbf{9}} \text { (g) }\end{array}$ & 4.6 & 4.5 & 4.5 & 2.2 & 1.5 & 1.4 & 0.7 & 0.7 & 0.6 \\
\hline Porosity Index \% & $\begin{array}{l}97 . \\
9\end{array}$ & $\begin{array}{l}95 . \\
6\end{array}$ & $\begin{array}{l}93 . \\
8\end{array}$ & $\begin{array}{l}43 . \\
1\end{array}$ & $\begin{array}{l}34 . \\
9\end{array}$ & $\begin{array}{l}33 . \\
3\end{array}$ & $\begin{array}{l}14 . \\
6\end{array}$ & $\begin{array}{l}13 . \\
7\end{array}$ & 12.2 \\
\hline
\end{tabular}

Table 9: The result of porosity index charcoal samples

\begin{tabular}{|l|l|l|l|}
\hline & $\mathbf{C}_{\mathbf{1}}$ & $\mathbf{C}_{\mathbf{2}}$ & $\mathbf{C}_{\mathbf{3}}$ \\
\hline Mass of sample $\mathbf{W}_{\mathbf{9}}(\mathbf{g})$ & 13.7 & 11.7 & 9.4 \\
\hline Mass of sample immersed in water $\mathbf{W}_{\mathbf{1 0}}(\mathbf{g})$ & 16.7 & 12.5 & 10.1 \\
\hline Mass of water absorbed $\left(\mathbf{W}_{\mathbf{1 0}}-\mathbf{W}_{\mathbf{9}}\right)(\mathbf{g})$ & 3 & 0.8 & 0.7 \\
\hline Porosity Index $\%$ & 21.9 & 6.8 & 7.4 \\
\hline
\end{tabular}

Table 10: Result of calorific value

\begin{tabular}{|l|l|}
\hline Sample & Net calorific value(MJ/kg) \\
\hline $\mathbf{P}_{\mathbf{1}}$ & 16.072 \\
\hline $\mathbf{P}_{\mathbf{2}}$ & 16.942 \\
\hline $\mathbf{P}_{\mathbf{3}}$ & 17.584 \\
\hline $\mathbf{P}_{\mathbf{4}}$ & 16.185 \\
\hline $\mathbf{P}_{\mathbf{5}}$ & 15.598 \\
\hline $\mathbf{P}_{\mathbf{6}}$ & 16.058 \\
\hline $\mathbf{P}_{\mathbf{7}}$ & 15.281 \\
\hline $\mathbf{P}_{\mathbf{8}}$ & 15.292 \\
\hline $\mathbf{P}_{\mathbf{9}}$ & 15.129 \\
\hline $\mathbf{C}_{\mathbf{1}}$ & 16.660 \\
\hline $\mathbf{C}_{\mathbf{2}}$ & 18.730 \\
\hline $\mathbf{C}_{\mathbf{3}}$ & 19.680 \\
\hline
\end{tabular}

Table 11: The results of proximate analyses of pellet and charcoal samples

\begin{tabular}{|l|l|l|l|l|l|l|}
\hline Sample & $\begin{array}{l}\text { Moisture } \\
\text { content \% }\end{array}$ & $\begin{array}{l}\text { Ash } \\
\text { content } \%\end{array}$ & $\begin{array}{l}\text { Bulk density } \\
\text { kg/m }\end{array}$ & $\begin{array}{l}\text { Porosity } \\
\text { index \% }\end{array}$ & $\begin{array}{l}\text { Calorific } \\
\text { value MJ/kg }\end{array}$ & $\begin{array}{l}\text { Burning rate } \\
\text { (g/min) }\end{array}$ \\
\hline $\mathbf{P}_{\mathbf{1}}$ & 4.9 & 8.5 & 524.3 & 97.9 & 16.072 & 2.38 \\
\hline $\mathbf{P}_{\mathbf{2}}$ & 3.0 & 6.0 & 556.4 & 95.6 & 16.942 & 2.27 \\
\hline $\mathbf{P}_{\mathbf{3}}$ & 2.0 & 3.7 & 567.1 & 93.8 & 17.584 & 2.27 \\
\hline $\mathbf{P}_{\mathbf{4}}$ & 2.6 & 10.5 & 731.4 & 43.1 & 16.185 & 1.79 \\
\hline $\mathbf{P}_{\mathbf{5}}$ & 2.9 & 13.3 & 740.7 & 34.9 & 15.598 & 1.47 \\
\hline $\mathbf{P}_{\mathbf{6}}$ & 3.2 & 10.5 & 750.0 & 33.3 & 16.058 & 2.17 \\
\hline $\mathbf{P}_{\mathbf{7}}$ & 2.9 & 15.0 & 770.7 & 14.6 & 15.281 & 2.17 \\
\hline $\mathbf{P}_{\mathbf{8}}$ & 3.7 & 14.0 & 791.4 & 13.7 & 15.292 & 2.00 \\
\hline $\mathbf{P}_{\mathbf{9}}$ & 5.2 & 13.2 & 792.9 & 12.2 & 15.129 & 1.85 \\
\hline $\mathbf{C}_{\mathbf{1}}$ & 0.0 & 16.7 & - & 21.9 & 16.660 & 1.09 \\
\hline $\mathbf{C}_{\mathbf{2}}$ & 2.0 & 4.1 & - & 6.8 & 18.730 & 1.67 \\
\hline $\mathbf{C}_{\mathbf{3}}$ & 0.0 & 1.6 & - & 7.4 & 19.680 & 1.06 \\
\hline
\end{tabular}




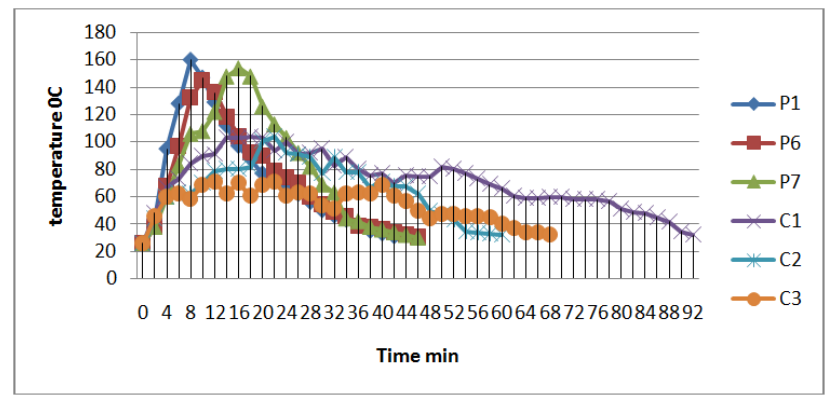

Figure 1: Temperature and time on burning 100g of pellet and charcoal taken at a particularpoint on the stove.

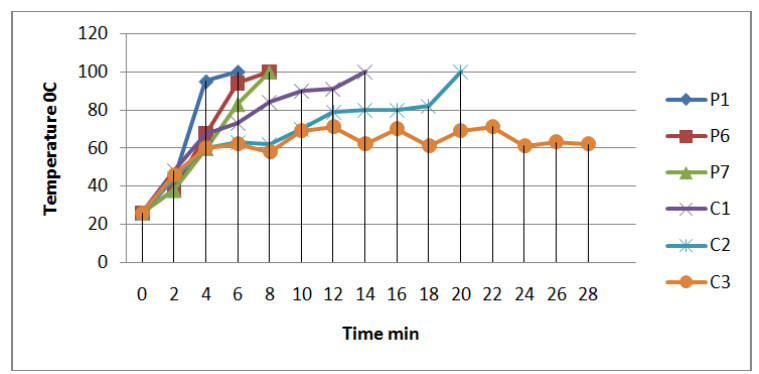

Figure 2: Water boiling test

\subsection{Discussions}

Significant differences in heating values were found among pellet samples. From result shown in Table 10 , the maximum calorific value of $17.589 \mathrm{MJ} / \mathrm{kg}$ was achieved at $\mathrm{P}_{3}$ with a compaction pressure of $34 \mathrm{MPa}$ with particle size of $425 \mu \mathrm{m}$. Also the minimum calorific value of $15.129 \mathrm{MJ} / \mathrm{kg}$ was achieved at $\mathrm{P}_{9}$ with a compaction pressure of $34 \mathrm{MPa}$ with particle size of $212 \mu \mathrm{m}$. The results in Table 11 shows that as the moisture content increases the heating value reduces. This was observed for pellet samples $\mathrm{P}_{1}, \mathrm{P}_{2}$ and $\mathrm{P}_{3}$, with moisture content $4.9 \%, 3 \%$, and $2 \%$ and heating value $16.072 \mathrm{MJ} / \mathrm{kg}, 16.942 \mathrm{MJ} / \mathrm{kg}$ and $17.584 \mathrm{MJ} / \mathrm{kg}$ respectively. Higher moisture content implies a lower calorific value as each unit mass of fuel contains less oven dry biomass which is the part of the fuel that actually undergoes combustion to release heat [13]. Also the result in Table 11 shows that the ash content also affects the heating value. $\mathrm{P}_{5}$ and $\mathrm{P}_{7}$ have the same moisture content of 2.9 and ash contents of $13.3 \%$ and $15 \%$ and calorific value of $15.598 \mathrm{MJ} / \mathrm{kg}$ and $15.281 \mathrm{MJ} / \mathrm{kg}$ respectively. This was in line with the observation of [14].

From the combustion test as shown in Fig. 1, pellet sample $\mathrm{P}_{1}$, a peak temperature of $160^{\circ} \mathrm{Cwas}$ achieved in 8 minutes. Thereafter, it takes 26 minutes for the temperaturesto dropto $60^{\circ} \mathrm{C}$. This shows that useful heat can be sustained for upward of 26 minutes before going extinct. For pellet sample $\mathrm{P}_{6}$, a peak temperature of $145^{\circ} \mathrm{C}$ was achieved 10 minutes. Thereafter, it takes 28 minutes for thetemperaturesto dropto $60^{\circ} \mathrm{C}$. This shows that useful heat can be sustained for upward of 28 minutes before going extinct. Alsopellet sample $\mathrm{P}_{7}$, a peak temperature of $154^{\circ} \mathrm{C}$ was achieved 16 minutes. Thereafter, it takes 32 minutes for the temperatures todrop to $60^{\circ} \mathrm{C}$.This shows that useful heat can be sustained for upward of 32 minutes before going extinct. For the charcoal samples $\mathrm{C}_{1}$, a peak temperature of $104^{\circ} \mathrm{C}$ was achieved in 18 minutes. Thereafter, it takes 62 minutes for the temperatures todrop to $60^{\circ} \mathrm{C}$. For charcoal sample $\mathrm{C}_{2}$, a peak temperature of $104^{\circ} \mathrm{C}$ was achieved in 22 minutes. Thereafter, it takes 46 minutes for the temperatures todrop to $60^{\circ} \mathrm{C}$. Also charcoal sample $\mathrm{C}_{3}$, a peak temperature of $71^{\circ} \mathrm{C}$ was achieved in 22 minutes. Thereafter, it takes 42 minutes for the temperatures to dropto $60^{\circ} \mathrm{C}$. It was observed that all the pellet samples were burnt completely in a domestic charcoal cooking stove and gave a uniform flame under free convection with pale yellow flame throughout and very little smoke and as the combustion continues, the pellet burns without smoke. The charcoal samples burns irregularly and require a forced convection to burn completely and particularly during ignition.

From water boiling test result shown in Fig. 2, it evaluates the suitability of pellets for use as domestic fuel. Forpellet sample $\mathrm{P}_{1}, 100 \mathrm{~g}$ of fuel achieved $100^{\circ} \mathrm{C}$ in 6 minutes to boil $500 \mathrm{ml}$ of water. For pellet samples $\mathrm{P}_{6}$ andP $\mathrm{P}_{7}, 100 \mathrm{~g}$ of each fuel achieved $100^{\circ} \mathrm{C}$ in 8 minutes each to boil $500 \mathrm{ml}$ of water. For charcoal sample $\mathrm{C}_{1}$, $100 \mathrm{~g}$ of fuel achieved $100^{\circ} \mathrm{C}$ in 14 minutes to boil $500 \mathrm{ml}$ of water. For charcoal sample $\mathrm{C}_{2}, 100 \mathrm{~g}$ of fuel achieved $100^{\circ} \mathrm{C}$ in 20 minutes to boil $500 \mathrm{ml}$ of water. For charcoal sample $\mathrm{C}_{3}$ boiling was not achieved. 


\section{Conclusion}

The study was primarily motivated by the large quantities of rice husk waste seen lying at rice mill dump site and burnt in open fire - causing environmental pollution. In converting the rice husk into pellets, the physical and combustion characteristics of the pellets were investigated, and comparative study was also conducted with charcoal in order to establish suitability for use as domestic fuel. The work draws the following conclusion: high efficient and durable solid fuel for domestic use was produced, from rice husk, with calorific value ranging from $15.129-17.589 \mathrm{MJ} / \mathrm{kg}$. The rice husk pellet fuel burns uniformly under free convection with pale yellow flame and very little smoke, but the charcoal burns irregularly and requires forced convection particularly during ignition.More so, because of the good physical and combustion characteristic of the rice husk pellet, it can conveniently substitute for charcoal as a domestic fuel.

\section{Reference}

[1]. O.P. Fapetu, Production of Charcoal from Tropical Biomass for Industrial and Metallurgical Process. Nigerian Journal of Engineering Management. 1(2), 2000, 34-37.

[2]. M. Sudhagar, Recent Developments in Biomass Densification Technology. Institute of Biological Engineering; Annual Conference. Biological and Agricultural Engineering Department University of Georgia, 2008.

[3]. P.D. Grover, and S.K. Mishra, Biomass Briquetting Technology and Practice. Food and Agriculture Organization of the United Nations, Bangkok. Regional Wood Energy Development Program (RWEDP), 1996.

[4]. AEBIOM, Pellets for small-scale domestic heating systems, 2007. www.aebiom.org

[5]. F. Philip, Nigeria Looking for Firewood Alternatives, Palm/Deforestation Watch, 2007.www.//deforestationwatchorg.org

[6]. ASABE Standards, Densified products for bulk handling-definitions and method. ASABE S269.5. In: ASABE Standards, American Society of Agricultural and Biological Engineers, St. Joseph, MI, 2012, p 1-8

[7]. American Society for Testing and Materials (ASTM). D2017 - 98 Standard Test Method of Accelerated Laboratory Test of Natural Decay Resistance of Woods, decay, evaluation, laboratory, natural, resistance and subjected to termite bioassay according to nochoice test procedure based upon AWPA E1-97 (AWPA, 1998) and ASTM D 3345-74 (ASTM, 1998) standard: pp 111 - 175

[8]. American Society for Testing and Materials (ASTM). Standard Methods of Evaluating the Fibre and Panel Materials. ASTM D 1037 - 91. Annual book of ASTM Standards, 04.09 Wood, Philadelphia, PA. 1991, pp. 169 - 191. Properties of Wood-Based

[9]. W.F. Montgomery, Standard Laboratory Test Methods for Coal and Coke in Analytical Methods for Coal and Coal Products, Academic Press, New York, 1978, pp. 194-224.

[10]. T.E. Omoniyi, and A.O.Olorunnisola, Experimental Characterization of Bagasse Biomass Material for Energy Production; International Journal of Engineering and Technology Volume 4 No. 10, October 2014.

[11]. T.U. Onuegbu, U.E. Ekpunobi, I.M. Ogbu, M.O. Ekeoma, and F.O. Obumselu, Comparative Studies of Ignition Time and Water Boiling Test of Coal and Biomass Briquettes Blend; (www.arpapress.com)IJRRAS 7 (2), 2011.

[12]. H. Kim, S. Kazuhiko, and S. Masayoshi, Bio-coal Briquette as a Technology for Desulphurdizing and Energy Saving. In T. Yamada ed. Chapter 34, 2001, pp 33 - 75.

[13]. The Carbon Trust, Biomass heating; A Practical Guide for Potential Users, 2008, www.carbontrust.co.uk

[14]. S. V. Loo, and J. Koppejan, The Handbook of Biomass Combustion and Co-firing. Earth scan, London, 2008. 